\title{
LH receptor induction and ovulation rate in mice selected for litter size and body weight
}

\author{
D. Pomp, E. J. Eisen and A. J. Ziecik* \\ Department of Animal Science, North Carolina State University, Box 7621, Raleigh, \\ North Carolina 27695-7621, U.S.A.
}

\begin{abstract}
Summary. Female mice from lines which had undergone long-term single trait and antagonistic index selection for litter size and body weight were analysed for ovulation rate and $\mathrm{LH}$ receptor induction. Compared to randomly selected controls, selection for large litter size increased ovulation rate $(60 \% ; P<0.001)$ and decreased $\mathrm{LH}$ receptor induction per $\mu \mathrm{g}$ ovarian DNA $(87 \% ; P<0.01)$. Selection for large body weight increased ovulation rate $(18 \% ; P<0.001)$, but did not lead to a significant correlated response in $\mathrm{LH}$ receptor induction. Index selection for large litter size and small body weight increased ovulation rate $(14 \% ; P<0.01)$ and decreased $\mathrm{LH}$ receptor induction $(72 \% ; P<0.01)$, while index selection for small litter size and large body weight did not significantly alter either ovulation rate or LH receptor induction. LH receptor quantities in testes of males from the 5 lines did not exhibit the among-line profile which was observed in ovaries of females.

These results confirm the role of ovulation rate in mediation of the positive genetic correlation between litter size and body weight in mice. Increased ovulation rate in mice selected for large litter size may be due to mechanisms associated with $\mathrm{LH}$ receptors as well as factors related to growth. In contrast, increased ovulation rate in mice selected for large body weight may be due exclusively to factors related to growth.
\end{abstract}

Keywords: ovulation rate; LH receptors; ovary; selection; mice

\section{Introduction}

Ovulation rate is known to be an important component in determination of reproductive performance of female mice. Ovulation rate has been increased by direct selection (Bradford, 1969; Land \& Falconer, 1969) and as a correlated response to selection for litter size, body weight or testes weight (MacArthur, 1944; Falconer, 1960; Bradford, 1968, 1971; Land, 1970; Islam et al., 1976; Joakimsen \& Baker 1977; Bakker et al., 1978; Durrant et al., 1980; Spruill \& Eisen, 1985). The increases in ovulation rate that accompany selection for litter size or body weight are thought to be a common link which mediates the positive genetic correlation between reproduction and growth (reviewed by Brien, 1986). However, the underlying physiological mechanisms responsible for these increases in ovulation rate remain obscure.

Spearow \& Bradford (1983) examined ovulation rate and the induction of ovarian LH receptors in lines of mice selected for increased litter size or increased post-weaning weight gain. While both modes of selection increased ovulation rate, $\mathrm{LH}$ receptors were reduced in response to selection for litter size and increased in response to selection for weight gain. This indicated that either $\mathrm{LH}$ receptor induction and ovulation rate are independent, or that ovulation rate had increased in the two lines by different mechanisms.

*Present address: Institute of Animal Physiology, University of Agriculture and Technology, Olsztyn, Poland. 
The present study investigated the relationship of $\mathrm{LH}$ receptor induction and ovulation rate and explored the possible role of this relationship in mediating the positive correlation between litter size and body weight. Lines of mice which had undergone long-term single trait and antagonistic index selection for litter size and body weight (Eisen, 1978) were analysed for ovarian LH receptor induction and ovulation rate. Receptors were also measured in testes to examine the possibility of a genetic correlation between males and females in expression of this trait.

\section{Materials and Methods}

Lines of mice. Mice were from selected lines derived from the random-bred ICR population (Eisen, 1978). Single trait and antagonistic index selection for litter size and body weight were carried out for 23 generations, followed by 26 generations of relaxed selection. Lines included: $\mathrm{L}+$, increased litter size; $\mathrm{W}+$, increased 6-week body weight; $\mathrm{L}-\mathrm{W}+$, decreased litter size and increased 6-week body weight; $\mathrm{L}+\mathrm{W}-$, increased litter size and decreased 6-week body weight; and $\mathrm{K}$, a randomly selected control line.

Mice were housed in cages with food and water supplied ad libitum. Females evaluated for ovarian LH receptor induction were fed Purina Mouse Chow 5005 (Ralston Purina Co., St Louis, MO) from weaning at 21 days until measurement at 26 days. Females evaluated for spontaneous ovulation rate were fed Purina Laboratory Chow 5001 from weaning at 21 days until 8 weeks, at which time they were randomly allocated to either Mouse Chow or Laboratory Chow until measurement between 11 and 12 weeks, in order to investigate effects of diet on ovulation rate (results not presented). Males evaluated for testicular LH receptors were fed Laboratory Chow from weaning at 21 days until measurement at $12.5-14.5$ weeks. Room temperature was maintained at $21^{\circ} \mathrm{C}$ with a controlled light:dark cycle of $12 \mathrm{~h}: 12 \mathrm{~h}$ with lights on at $07: 00 \mathrm{~h}$. All mice were reared in a standardized post-natal fraternity size of 8 young from birth until weaning.

Natural ovulation rate. Within each line, 40 females were caged at 11 weeks with random males of the same line. Day of mating was determined by the presence of a vaginal plug between 08:00 and 09:00 h. On the day of mating, at 12:00-15:00 $\mathrm{h}$, females were weighed, killed by cervical dislocation and their oviducts excised and placed in saline $(0.9 \%(\mathrm{w} / \mathrm{v}) \mathrm{NaCl})$. One-cell embryos were removed from the oviducts by incising the oviducal wall at the site of the embryo cumulus bulge. Embryos were freed of cumulus cells by short exposure to hyaluronidase (Sigma, St Louis, $\mathrm{MO})$ and counted under a dissecting microscope $(\times 60)$.

LH receptor induction. LH receptors were induced in 20 sexually immature females in each of the 5 lines according to a modified technique based on the model of Spearow \& Bradford (1983). At 22 days anaesthetized (methoxyflurane; Pittman-Moore, NJ) females were treated with a subcutaneous Silastic implant $(\sim 1 \mathrm{~cm})$ consisting of diethylstilboestrol (Sigma) suspended in silicone elastomer diluted with 200 Fluid (Dow Corning, Midland, MI). At 24 and 25 days, females were injected with $100 \mu \mathrm{g}$ pig FSH (Burns-BIOTEC; Omaha, NE) twice daily. Preliminary dose-response studies determined this dose to be maximal. At 26 days, females were weighed, killed by cervical dislocation and their ovaries excised and placed in $0.5 \mathrm{~m}$-phosphate-buffered saline (PBS).

Untreated adult (12.5-14.5 weeks) males were used for measurement of quantity of testicular LH receptors. In each of the 5 lines, 20 males were weighed, killed by cervical dislocation and their testes excised and placed in PBS.

$L H$ receptor binding analysis. After excision, ovaries and testes were cleaned of excess fat and connective tissue, weighed and stored in cryogenic tubes in liquid nitrogen at $-196^{\circ} \mathrm{C}$ for a maximum interval of 4 weeks. $\mathrm{LH}$ receptor binding analyses were concurrent for either all ovaries or all testes. After thawing, pairs of gonads were homogenized in $1.6 \mathrm{ml}$ (ovaries) or $5 \mathrm{ml}$ (testes) Dulbecco's PBS (Gibco) at $4^{\circ} \mathrm{C}$ with a Polytron homogenizer (Brinkman Instruments, Westbury, NY) by two 7 -sec bursts. Gonad homogenates were assayed spectrophotometrically for DNA using the diphenylamine reaction as described by Burton (1956).

Purified hCG (CR-121; 13450 i.u./mg) was provided by the Center for Population Research at the NICHHD. The hCG was labelled by the chloramine-T method of Catt \& Dufau (1975). Specific activities of labelled hCG were determined by self-displacement analysis in the radioligand receptor assay (Ketelslegers et al., 1975) and varied in two assays from 33 to 40 c.p.m./pg. The corrected specific activities were 42 to $51 \mu \mathrm{Ci} / \mu \mathrm{g}$. The tissue homogenates were incubated overnight with ${ }^{125}$ I-labelled hCG in polystyrene tubes in a shaker bath at $22^{\circ} \mathrm{C}$. The incubation mixture consisted of $0.1 \mathrm{ml}$ Dulbecco's PBS containing $5 \mathrm{mM}-\mathrm{MgCl}_{2}$ and $0.1 \%$ BSA (incubation buffer; $\mathrm{pH} 7 \cdot 2$ ), $0.1 \mathrm{ml}$ incubation buffer containing $\sim 100000$ c.p.m. ${ }^{125} \mathrm{I}$-labelled hCG and $0.25 \mathrm{ml}$ ovarian homogenate. For testes, the incubation mixture consisted of $0.15 \mathrm{ml}$ incubation buffer, $0.1 \mathrm{ml}$ incubation buffer containing labelled hCG and $0.1 \mathrm{ml}$ homogenate. The addition of $100000 \mathrm{c.p} . \mathrm{m} .{ }^{125} \mathrm{I}$-labelled hCG to appropriate aliquants of gonadal tissues was found to be saturating, and binding increased with increasing amounts of tissue.

Non-specific binding was determined in matched samples in the presence of excess ( 20 i.u./tube) unlabelled hCG (LyphoMed, Inc., Chicago, IL). To separate receptor-bound from free ${ }^{125} \mathrm{I}$-labelled hCG, $1.5 \mathrm{ml}$ ice-cold PBS were added and the tubes centrifuged at $2000 \mathrm{~g}$ for $30 \mathrm{~min}$. Supernatants were removed and the pellet washed again with an additional $1.5 \mathrm{ml}$ PBS and re-centrifuged. Pellets were counted for ${ }^{125} \mathrm{I}$ in a gamma counter. Non-specific binding was $<1 \%$ of the total ${ }^{125}$ I added. 
Statistical analysis. For all traits measured except LH receptor induction in females, least-squares means were obtained (Harvey, 1979) from a statistical model which included an overall mean, a fixed line effect and a random residual effect. Additional models included body weight or age as covariates when appropriate. For ovulation rate, adjustment was made for diet and diet $x$ line interaction effects. Duncan's multiple range test was used for all line comparisons.

Due to significant heterogeneity of variances detected using Cochran's (1941) and Hartley's (1950) tests and lack of significant improvement following log or square-root transformations, data on LH receptor induction in females were analysed according to Tamhane's (1976) theorems for comparison of means with heterogeneous variances (Gill, 1977).

\section{Results}

\section{Natural ovulation rate}

Least-squares means of body weight at 11-13 weeks of age (mating) are presented in Table 1 and of ovulation rate in Fig. 1. Line effects were significant for both traits $(P<0.0001)$. Line ranking for mating weight was: $\mathbf{W}+, \mathrm{L}+, \mathrm{L}-\mathrm{W}+, \mathrm{K}, \mathrm{L}+\mathrm{W}-$. In relation to the unselected control line $(K)$, selection for increased litter size $(L+)$ increased ovulation rate by 8.5 ova $(60 \%$; $P<0.001)$, while selection for increased body weight $(\mathrm{W}+)$ increased ovulation rate by 2.5 ova (18\%; $P<0.001)$. The index selection line $\mathrm{L}+\mathrm{W}-$, containing a component for increased litter size, increased ovulation rate by 1.9 ova $(13 \% ; P<0.01)$. In contrast, the index selection line $\mathbf{L}-\mathbf{W}+$, containing a decreased litter size component, exhibited no significant decrease in ovulation rate relative to the control line.

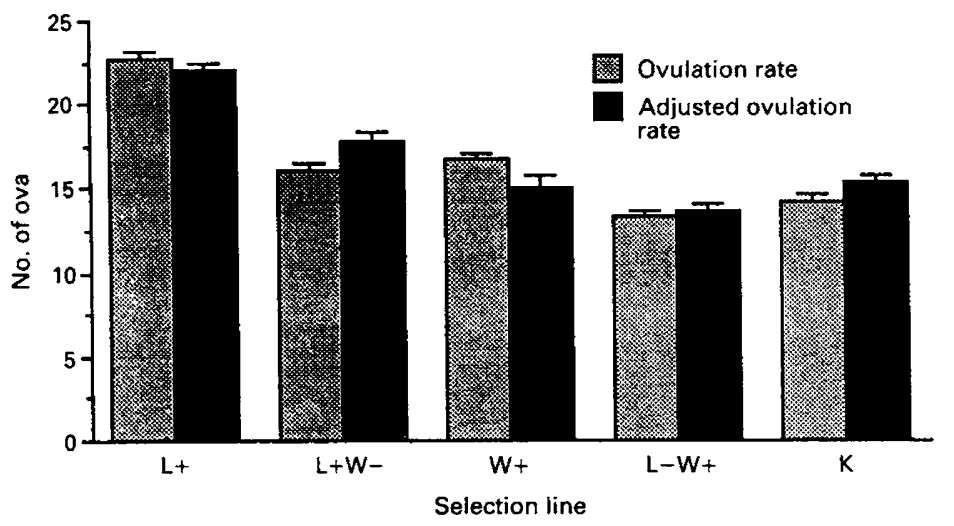

Fig. 1. Least-squares means and s.e. of ovulation rate in 11-13-week-old female mice, nonadjusted and adjusted by analysis of covariance for mating weight.

Table 1. Least-squares means for body weight at 11-13 weeks of age for female mice analysed for ovulation rate

\begin{tabular}{lcc}
\hline Line & Body wt (g) & s.e. $\dagger$ \\
\hline L+ & $34 \cdot 94^{\text {b }}$ & 0.44 \\
L+W - & $28 \cdot 16^{\mathrm{e}}$ & 0.46 \\
W + & $41 \cdot 09^{\mathrm{a}}$ & 0.46 \\
$\mathrm{~L}-\mathrm{W}+$ & $32 \cdot 19^{\mathrm{c}}$ & 0.45 \\
$\mathrm{~K}$ & $29 \cdot 64^{\mathrm{d}}$ & 0.44 \\
\hline
\end{tabular}

Means with no superscript in common are different $(P<0.05)$.

†Standard error of line means; 35-38 females per line. 
Table 2. Least-squares means for body weight and ovary weight in 26-day-old female mice pretreated with diethylstilboestrol and FSH

\begin{tabular}{lcc}
\hline Line & Body wt (g) & Ovary wt $\dagger^{(\mathrm{mg})}$ \\
\hline $\mathrm{L}+$ & $20 \cdot 9^{\mathrm{b}}$ & $7 \cdot 8^{\mathrm{b}}$ \\
$\mathrm{L}+\mathrm{W}-$ & $16 \cdot 3^{\mathrm{d}}$ & $4 \cdot 3^{\mathrm{d}}$ \\
$\mathrm{W}+$ & $22 \cdot 2^{\mathrm{a}}$ & $9 \cdot 7^{\mathrm{a}}$ \\
L-W+ & $18 \cdot 7^{\mathrm{c}}$ & $5 \cdot 8^{\mathrm{c}}$ \\
K & $17 \cdot 8^{\mathrm{c}}$ & $7 \cdot 7^{\mathrm{b}}$ \\
s.e. $\ddagger$ & $0 \cdot 4$ & $0 \cdot 4$ \\
\hline
\end{tabular}

Within columns, means with no superscript in common are different $(P<0 \cdot 05)$.

†Both ovaries.

†Standard error of each line mean; 20 females per line.

Regression of ovulation rate on mating weight was homogeneous across lines $(b=0.33 \pm$ $0.07)$, and the within-line phenotypic correlation was $r=0.35(P<0.0001)$. Least-squares means of ovulation rate adjusted by covariance analysis for mating weight are presented in Fig. 1 . Mice in Line $\mathrm{L}+$ remained the highest in ovulation rate, and were followed by those in Line $\mathrm{L}+\mathrm{W}-$, for which the increased litter size component is now more evident. $\mathrm{W}+$ and $\mathrm{K}$ mice ranked third and were not different from each other, while $\mathrm{L}-\mathrm{W}+$ mice, with the decreased litter size component, now ranked last.

\section{$L H$ receptor induction in females}

Least-squares means of body weight and ovary weight at 26 days are presented in Table 2 . Line effects were significant for both traits $(P<0 \cdot 0001)$.

Least-squares means of induced LH receptors are presented in Fig. 2. Numbers of LH receptors differed among lines $(P<0.0001)$. Rankings of the lines were relatively consistent among the 3 methods of measurement. Lines $\mathrm{W}+, \mathrm{L}-\mathrm{W}+$ and $\mathrm{K}$ had the highest numbers of induced $\mathrm{LH}$ receptors and were not different from each other $(P>0.05)$, while $\mathrm{L}+$ and $\mathrm{L}+\mathrm{W}-$ had the lowest hCG binding. On a per ovary basis, Lines $L+$ and $L+W-$ were not different from each other, while on a per mg ovary and per $\mu$ g ovarian DNA basis, $\mathrm{L}+$ was lower than $\mathrm{L}+\mathrm{W}-$. Line $\mathrm{L}+$ exhibited an $87 \%$ decrease $(P<0.01)$ in LH receptors (per $\mu \mathrm{g}$ ovarian DNA) relative to Line $\mathrm{K}$ while the decrease in $\mathrm{L}+\mathrm{W}-$ was $72 \%(P<0.01)$.

Least-squares means of induced $\mathrm{LH}$ receptors per ovary and per mg ovary adjusted by analysis of covariance for 26-day body weight are presented in Table 3. An association of body weight with LH receptor induction is evident from changes in ranking of lines relative to the unadjusted data. The major alteration in comparison with the unadjusted means involved a relative decrease in $\mathrm{LH}$ receptor induction in Line $\mathbf{W}+$, the heaviest line, and a relative increase in Line $\mathbf{L}+\mathrm{W}-$, the lightest line. This positive phenotypic association between body weight and $\mathrm{LH}$ receptor induction is further supported by positive within-line correlations of $0.35(P<0.0005)$ between body weight and hCG binding per ovary and $0.28(P<0.01)$ between body weight and hCG binding per $\mathrm{mg}$ ovary. Adjustment for body weight reduced the number of induced LH receptors in Line $\mathrm{L}+$ mice to values not different from zero.

\section{$L H$ receptors in males}

Least-squares means of body weight and testis weight are presented in Table 4. Line effects were significant for both traits $(P<0.0001)$. Weights were not adjusted for age due to non-significant within-line phenotypic correlations between age and body weight and age and testis weight $(P>0.05)$. 


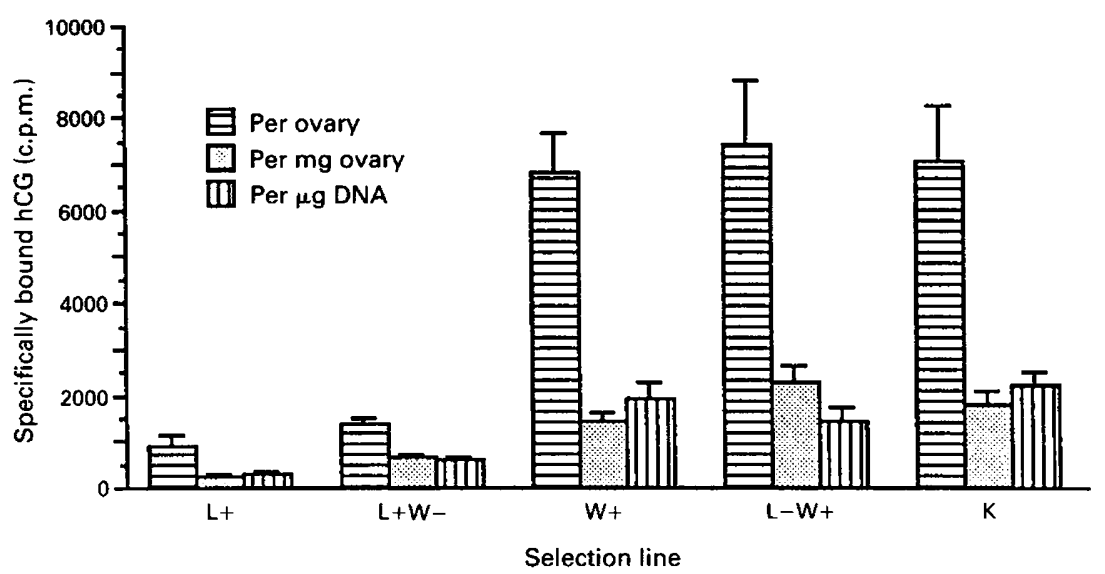

Fig. 2. Numbers of ovarian LH receptors in 26-day-old female mice pretreated with diethylstilboestrol and FSH. Data are least-squares means and s.e. of c.p.m. specifically bound ${ }^{125}$ I-labelled hCG; 20 females per line.

Table 3. Number of ovarian $\mathrm{LH}$ receptors $\dagger$ in $26-$ day-old mice pretreated with diethylstilboestrol and FSH, adjusted for 26-day-body weight $\ddagger$

\begin{tabular}{lcr}
\hline Line & Per ovary & Per mg ovary \\
\hline $\mathrm{L}+$ & $-356 \pm 951^{\mathrm{c}}$ & $-1 \pm 238^{\mathrm{c}}$ \\
$\mathrm{L}+\mathrm{W}-$ & $3549 \pm 1053^{\mathrm{b}}$ & $1060 \pm 264^{\mathrm{b}}$ \\
$\mathrm{W}+$ & $4483 \pm 1076^{\mathrm{b}}$ & $959 \pm 269^{\mathrm{b}}$ \\
$\mathrm{L}-\mathrm{W}+$ & $7764 \pm 865^{\mathrm{a}}$ & $2342 \pm 217^{\mathrm{a}}$ \\
$\mathrm{K}$ & $8108 \pm 905^{\mathrm{a}}$ & $2003 \pm 227^{\mathrm{a}}$ \\
\hline
\end{tabular}

Within columns, means with no superscript in common are different $(P<0.05)$.

†Least-squares means ( \pm s.e.) of c.p.m. specifically bound ${ }^{125}$ I-labelled hCG.

¥Data analysed by comparison of means with heterogeneous variance (Gill, 1977), adjusted by analysis of covariance; 20 females per line.

In all cases, binding of ${ }^{125}$ I-labelled hCG was different among lines $(P<0.0001)$. Ranking of lines was relatively consistent among the 3 methods of measurement given in Table 4 , and closely paralleled that for body weight. However, a within-line association between testicular $\mathrm{LH}$ receptor quantity and body weight was not found in this study. The within-line phenotypic correlation between body weight and hCG binding per testis was not significant $(r=-0.04 ; P>0 \cdot 75)$.

\section{Discussion}

Single-trait selection for increased litter size $(\mathrm{L}+)$ or increased body weight $(\mathrm{W}+)$ led to positive correlated responses in natural ovulation rate. This result confirms similar findings for the same lines (Durrant et al., 1980; Spruill \& Eisen, 1985) and for similarly selected lines (MacArthur, 1944; Falconer, 1960; Bradford, 1968, 1971; Land, 1970; Joakimsen \& Baker, 1977). Index selection for high litter size and low body weight $(\mathrm{L}+\mathrm{W}-)$ also led to a correlated increase in ovulation rate, 
Table 4. Least-squares means for body weight, testis weight and number of testicular LH receptors in 12.5-14.5-week-old male mice

\begin{tabular}{|c|c|c|c|c|c|}
\hline \multirow[b]{2}{*}{ Line } & \multirow[b]{2}{*}{$\begin{array}{c}\text { Body wt } \\
\text { (g) }\end{array}$} & \multirow[b]{2}{*}{$\begin{array}{l}\text { Testis wt } \\
\text { (mg) }\end{array}$} & \multicolumn{3}{|c|}{ LH receptors $\dagger$} \\
\hline & & & $\begin{array}{c}\text { Per } \\
\text { testis }\end{array}$ & $\begin{array}{c}\text { Per } \\
\text { mg testis }\end{array}$ & $\begin{array}{c}\text { Per } \\
\mu \mathrm{g} \text { DNA }\end{array}$ \\
\hline $\mathbf{L}+$ & $41 \cdot 9^{b}$ & $112^{c}$ & $91142^{b}$ & $815^{b}$ & $2741^{b c}$ \\
\hline $\mathbf{L}+\mathbf{W}-$ & $33 \cdot 0^{d}$ & $115^{c}$ & $76810^{\text {cd }}$ & $683^{c}$ & $2504^{\mathrm{c}}$ \\
\hline $\mathbf{w}+$ & $48 \cdot 5^{a}$ & $132^{b}$ & $130430^{\mathrm{a}}$ & $994^{\mathrm{a}}$ & $3515^{a}$ \\
\hline $\mathbf{L}-\mathbf{W}+$ & $40 \cdot 2^{b}$ & $144^{a}$ & $105638^{b}$ & $735^{\mathrm{bc}}$ & $3122^{b}$ \\
\hline $\mathbf{K}$ & $36 \cdot 2^{c}$ & $115^{c}$ & $75201^{d}$ & $657^{\mathrm{c}}$ & $2393^{c}$ \\
\hline s.e.t & 0.6 & 3 & 5279 & 39 & 162 \\
\hline
\end{tabular}

Within columns, means with no superscript in common are different $(P<0.05)$.

†Least-squares means ( \pm s.e.) of c.p.m. specifically bound ${ }^{125}$ I-labelled hCG. †tandard error of each line mean; 20 males per line.

though of a lesser magnitude than the increase in $\mathrm{L}+$. This relatively moderate increase may be due to negative effects contributed by the decreased body weight component, and to a weaker selection intensity placed on the increased litter size component. Index selection for low litter size and high body weight $(L-W+)$ did not significantly change ovulation rate relative to the control line $(K)$. In this case, the increased body weight component, acting via a positive genetic correlation with ovulation rate, may be balancing any detrimental effects of selection for decreased litter size on ovulation rate.

Single-trait selection for increased litter size led to a dramatic reduction in induced ovarian $\mathbf{L H}$ receptors, while selection for increased body weight did not significantly alter receptor numbers relative to the control line. Index selection components related to increasing means of traits (the positive litter size and body weight components of mice in Lines $L+W-$ and $L-W+$, respectively) led to similar patterns of $\mathrm{LH}$ receptor induction as their direct selection counterparts (Lines $\mathrm{L}+$ and $\mathrm{W}+$ ). $\mathrm{L}+\mathrm{W}-$ females exhibited a significant reduction in induced $\mathrm{LH}$ receptors, while $\mathbf{L}-\mathbf{W}+$ females were not significantly different from control females. On the other hand, index selection components related to decreasing means of traits (the negative litter size and body weight components of Lines $\mathrm{L}-\mathrm{W}+$ and $\mathrm{L}+\mathrm{W}-$, respectively) did not appear to have an effect. This observation is tenuous, however, due to lack of comparison with lines directly selected for decreased litter size or decreased body weight.

It would therefore appear that ovulation rate has been increased in $\mathrm{L}+$ mice, at least in part, by mechanisms which have not been enhanced by selection in $W+$ mice. These mechanisms may be related to decreased $\mathrm{LH}$ receptor induction, and would be representative of additive gene effects which are not part of the pleiotropic gene effects responsible for the positive genetic correlation between reproduction and growth in mice. This suggests that selection for increased litter size leads to an increase in ovulation rate which is caused by at least two separate mechanisms. One may involve a decrease in $\mathrm{LH}$ receptor induction which is not exhibited in mice selected for increased body weight, and the other would involve factors related to growth, leading to an increase in ovulation rate in mice selected for either trait. Some possibilities include an increase in circulating gonadotrophin concentrations (Land, 1970), increased ovarian sensitivity (McLaren, 1962; Durrant et al., 1980), decreased inhibin activity as observed in Booroola sheep (Piper \& Bindon, 1988), the activities of growth hormone and growth factors on follicular development and regulation (May et al., 1987), and the involvement of prolactin, adrenal and thyroid hormones and central nervous system neurotransmitters in mediating relationships between growth and ovulation rate (Brien, 1986).

These results both confirm and contrast those of Spearow \& Bradford (1983) who found that selection for litter size decreased ovarian $\mathrm{LH}$ receptor induction. However, selection for post-weaning 
weight gain (Line $\mathrm{G}$ ) significantly increased $\mathrm{LH}$ receptor induction relative to controls in the study of Spearow and Bradford (1983) but not in the present study.

Several possible explanations exist for these contradictory results, all relating to inherent differences between the two selection lines in question, Line $W+$ and Line $G$. The $W+$ line in the present study was selected from a base population of random-bred ICR mice, while Line G was selected from a totally different base population composed of a 4-way cross of inbred lines. In addition, selection in $\mathrm{W}+$ was for increased 6-week body weight, whereas selection in $\mathrm{G}$ was for high post-weaning weight gain. While both modes of selection increased growth rates and body weights, the mechanisms involved may have differed. For example, while adult females assessed for ovulation rate in these two studies had similar body weights at mating ( $42.2 \mathrm{~g}$ in $\mathrm{W}+$ and $44.7 \mathrm{~g}$ in $\mathrm{G}$ ), body weights at $\mathrm{LH}$ receptor induction measurement at 26 days were $56 \%$ higher in $\mathrm{W}+$ mice than in $\mathrm{G}$ mice. Furthermore, these lines appear to differ in correlated reproductive responses to selection. Mice in Line $\mathrm{W}+$ exhibit a lower increase in ovulation rate relative to controls than do those in Line G $(18 \%$ vs $73 \%)$, but litter size is increased in W + mice (Eisen, 1978) and not in G mice due to a decrease in embryo survival (Bradford, 1971). The genetic composition of the two selection lines may therefore be markedly different, and contrasting physiological bases for response to selection is not surprising.

For the present results, an assumption must be made that the method used for inducing $\mathbf{L H}$ receptors by treating immature females with diethylstilboestrol and FSH is an adequate model for the untreated adult female. Numerous studies have demonstrated genetic variation in the number of ovarian and testicular LH receptors in untreated animals (Purvis et al., 1978; Amador \& Bartke, 1981, 1982). Spearow (1980) has shown that the present method matures follicles and induces $\mathrm{LH}$ receptors in the immature female, while bypassing much of the normal feedback regulatory mechanisms controlling follicular development. Thus diethylstilboestrol and FSH treatment detects genetic differences in the induction of ovarian $\mathrm{LH}$ receptors in response to a uniform dose of gonadotrophins while minimizing the influence of genetic variation in endogenous gonadotrophin secretion.

The major physiological question which must be posed when considering the results of this study is how are the decreases in $\mathrm{LH}$ receptors in mice of the $\mathrm{L}+$ and $\mathrm{L}+\mathrm{W}-$ lines related to increases in ovulation rate in those lines? One possibility is that ovulation rate may not be dependent on the degree of $\mathrm{LH}$ receptor induction, and that the large differences detected among selection lines in $\mathrm{LH}$ receptors are not related to the differences found in ovulation rate. While this cannot be ruled out, the large degree of genetic variation observed in $\mathrm{LH}$ receptor induction, the fact that $\mathrm{LH}$ receptor induction is an important aspect of granulosa cell differentiation and ovarian follicular development (Mondschien \& Schomberg, 1980), and the knowledge that LH is a critical hormone in both the ovulatory process and feedback mechanisms regulating ovarian function, suggest that this trait should have importance in determining ovulation rate.

Spearow (1980) suggested that ovulation rate may be increased in mice selected for large litter size due to a decrease in $\mathrm{LH}$ receptor induction, resulting in a relative decrease in ovarian oestrogen production, thereby decreasing the negative feedback effects on FSH release in the pituitary. This would lead to an increase in circulating FSH concentrations, a stimulation of follicular development and an increase in ovulation rate. A decrease in LH receptors could lead to decreased ovarian androgen production, and thus lower the percentage of follicles undergoing atresia (Louvet et al., 1975; Bagnell et al., 1982). This would lead to a higher percentage of recruited follicles ultimately being ovulated, and thus to an increase in ovulation rate. Spearow (1986) has reported a $19 \%$ decrease in the incidence of atresia of large follicles in a line of mice (S1) selected for large litter size compared to controls.

Finally, epidermal growth factor has been shown to inhibit FSH dependent induction of LH receptors in cultured rat ovarian granulosa cells (Mondschien \& Schomberg, 1980), and also to enhance FSH binding in cultured pig granulosa cells (May et al., 1987). This and other growth factors may be involved in the increase of ovulation rate in mice of the $\mathrm{L}+$ and $\mathrm{L}+\mathrm{W}-$ selection lines. 
Ovulation rate was also increased in mice of the $\mathrm{W}+$ line, though not as dramatically as in $\mathrm{L}+$ mice, confirming the numerous observations of a positive correlation between body weight and ovulation rate in mice, sheep and, to a lesser extent, in pigs (Brien, 1986). Spearow \& Bradford (1983) suggested that the increased ovulation rate found in a line selected for post-weaning gain was due to an increased induction of LH receptors. In contrast, the present study detected no significant differences between the high body weight and control lines in LH receptor induction. These results suggest that selection for increased growth in different lines of mice may lead to correlated increases in ovulation rate through different mechanisms.

LH receptor quantities in testes from untreated, adult males of the 5 selection lines did not exhibit the same profile as did those from the ovaries. The large decrease in ovarian LH receptors in mice of the $\mathrm{L}+$ line and to a lesser extent in those of the $\mathrm{L}+\mathrm{W}$ - line was not apparent in testes from males of those lines. It would therefore appear that sex-differentiated expression of genes controlling LH receptor numbers may be occurring in these lines, and that this reproductive character is not genetically correlated in males and females. However, this result is not surprising considering that possible confounding factors of hormonal treatment, physiological state and age may render LH receptor traits significantly different in the two sexes.

Line ranking of testicular $\mathrm{LH}$ receptor quantities closely paralleled that found for body weight, although within-line testicular LH receptor number was not significantly associated with body weight. Selection of mice for large body weight or for large litter size increased LH receptors relative to control mice. The effect of selection for large body weight appears to be greater than that of selection for large litter size, and this is supported by the responses of the index-selected lines. In the $\mathrm{L}+\mathrm{W}-$ line, the increased $\mathrm{LH}$ receptors found in response to selection for litter size was completely counteracted by the effects of selection for small body weight. In contrast, the effect of selection for small litter size only partly counteracted the effect of selection for large body weight in the $\mathrm{L}-\mathrm{W}+$ line. Wolfe et al. (1981) found that binding of LH in testes was not different between two lines selected for high and low induced ovulation rate. On the other hand, Stalvey \& Payne (1983) clearly demonstrated the existence of genetic variation in testicular LH receptors among 4 inbred mouse strains. The results of the present study should be interpreted cautiously, considering that only one measurement was made on each male. LH secretion has been shown to follow a temporal pattern in male mice, with infrequent, discontinuous pulses (Coquelin \& Desjardins, 1982). This may affect the magnitude of LH receptors in the testes due to down-regulation mechanisms, depending on when the testes were collected relative to the LH pulses.

In conclusion, selection of mice for large litter size or large body weight led to correlated increases in natural ovulation rate. $\mathrm{LH}$ receptor induction was dramatically reduced in females selected for large litter size, but was unchanged in females selected for large body weight. These results indicate that in the lines of mice studied $\mathrm{LH}$ receptor induction is not a physiological basis for the positive genetic correlation between litter size and body weight. Increased ovulation rate in mice selected for large litter size may be due to mechanisms associated with $\mathrm{LH}$ receptors as well as factors related to growth. In contrast, increased ovulation rate in mice selected for large body weight may be due exclusively to factors related to growth. Conflicting results between this and other studies suggest that selection for increased growth in mice may lead to similar correlated reproductive responses through different physiological mechanisms, depending on the criterion of selection and the composition of the base population.

Paper no. 11531 of the Journal Series of the North Carolina Agricultural Research Service, Raleigh, 27695-7601. The use of trade names in this publication does not imply endorsement by the North Carolina Agricultural Research Service of the products named, nor criticism of similar ones not mentioned.

We thank Dr J. D. Armstrong, Dr J. H. Britt, Dr O. W. Robison and an anonymous referee for constructive reviews. A.J.Z. supported by USDA Grant 85-CRCR-1-1849 to J. H. Britt and K. L. Esbenshade. 


\section{References}

Amador, A. \& Bartke, A. (1981) Endocrinological Research. Mouse NewsLetter 65, 46.

Amador, A. \& Bartke, A. (1982) Endocrinological Research. Mouse NewsLetter 66, 77.

Bagnell, C.A., Mills, T.M., Costofi, A. \& Mahesh, V.B. (1982) A model for the study of androgen effects on follicular atresia and ovulation. Biol. Reprod. 27, 903-914.

Bakker, H., Wallinga, J.H. \& Politiek, R.D. (1978) Reproduction and body weight of mice after longterm selection for large litter size. J. Anim. Sci. 46, $1572-1580$.

Bradford, G.E. (1968) Selection for litter size in mice in the presence and absence of gonadotropin treatment. Genetics, Princeton 58, 283-295.

Bradford, G.E. (1969) Genetic control of ovulation rate and embryo survival in mice. I. Response to selection. Genetics, Princeton 61, 905-921.

Bradford, G.E. (1971) Growth and reproduction in mice selected for rapid body weight gain. Genetics, Princeton 69, 499-512.

Brien, F.D. (1986) A review of the genetic and physiological relationships between growth and reproduction in mammals. Anim. Breed. Abstr. 54, 975 997.

Burton, K. (1956) A study of the conditions and mechanisms of the diphenylamine reaction for colorimetric estimation of dioxyribonucleic acid. Biochemistry, N.Y. 62, 315-322.

Catt, K.J. \& Dufau, M.L. (1975) Gonadal receptors for luteinizing hormone and chorionic gonadotropin. Methods Enzymol. 37, 167-193.

Cochran, W.G. (1941) The distribution of the largest of a set of estimated variances as a fraction of their total. Ann. Eugen. 11, 47.

Coquelin, A. \& Desjardins, C. (1982) Luteinizing hormone and testosterone secretion in young and old male mice. Am. J. Physiol. 243, E257-E263.

Durrant, B.S., Eisen, E.J. \& Ulberg, L.C. (1980) Ovulation rate, embryo survival and ovarian sensitivity to gonadotrophins in mice selected for litter size and body weight. J. Reprod. Fert. 59, 329-339.

Eisen, E.J. (1978) Single-trait and antagonistic index selection for litter size and body weight in mice. Genetics, Princeton 88, 781-811.

Falconer, D.S. (1960) The genetics of litter size in mice. J. cell. comp. Physiol. 56, 153-167.

Gill, J.L. (1977) Multiple comparisons of means when variance is not homogeneous. J. Dairy Sci. 60, $444-449$.

Hartley, H.O. (1950) The maximum F-ratio as a shortcut test for heterogeneity of variance. Biometrika 37, 308.

Harvey, W.R. (1979) Least-squares analysis of data with unequal subclass numbers. USDA, ARS H-4. Beltsville, MD, U.S.A.

Islam, A.B.M.M., Hill, W.G. \& Land, R.B. (1976) Ovulation rate of lines of mice selected for testis weight. Genet. Res. 27, 23-32.

Joakimsen, O. \& Baker, R.L. (1977) Selection for litter size in mice. Acta agric. scand. 27, 301-318.
Ketelslegers, J.M., Knott, G.D. \& Catt, K.J. (1975) Kinetics of gonadotropin binding by receptors of the rat testis. Analysis by a nonlinear curve-fitting method. Biochemistry, N.Y. 14, 3075-3083.

Land, R.B. (1970) Genetic and phenotypic relationships between ovulation rate and body weight in the mouse. Genet. Res. 15, 171-182.

Land, R.B. \& Falconer, D.S. (1969) Genetic studies of ovulation rate in the mouse. Genet. Res. 13, 25-46.

Louvet, J.P., Harman, S.M., Schreiber, J.R. \& Ross, G.T. (1975) Evidence for a role of androgens in follicular maturation. Endocrinology 97, 366-372.

MacArthur, J.W. (1944) Genetics of body size and related characters. II. Satellite characters associated with body size in mice. Am. Nat. 78, 224-237.

May, J.V., Buck, P.A. \& Schomberg, D.W. (1987) Epidermal growth factor enhances [125I]Iodo-FollicleStimulating hormone binding by cultured porcine granulosa cells. Endocrinology 120, 2413-2420.

McLaren, A. (1962) The relation between natural fecundity and response to FSH. J. Endocr. 25, 137-144.

Mondschein, J.S. \& Schomberg, D.W. (1980) Growth factors modulate gonadotropin receptor induction in granulosa cell cultures. Science, N.Y. 211, 1179-1180.

Piper, L.R. \& Bindon, B.M. (1988) The genetics and endocrinology of the Booroola sheep F gene. In Proc. 2nd Int. Cong. Quant. Genet'ss, Raleigh, pp. 270-280. Eds B. S. Weir, E. J. Eisen, M. M. Goodman \& G. Namkoong. Sinauer, Sunderland.

Purvis, K., Clausen, O.P.F. \& Hansson, V. (1978) Decreased leydig cell responsiveness in the testicular feminized rat. Endocrinology 102, 1053-1060.

Spearow, J.L. (1980) The physiological basis of genetic differences in the ovulation rate of mice. Ph.D thesis, University of California at Davis.

Spearow, J.L. (1986) Changes in the kinetics of follicular growth in response to selection for large litter size in mice. Biol. Reprod. 35, 1175-1186.

Spearow, J.L. \& Bradford, G.E. (1983) Genetic variation in spontaneous ovulation rate and $\mathbf{L H}$ receptor induction in mice. J. Reprod. Fert. 69, 529-537.

Spruill, S.E. \& Eisen, E.J. (1985) Ovulation rate and embryo survival during gestation and the effects of ovariectomy on maternal nurturing ability. J. Anim. Sci. 61, 834-843.

Stalvey, J.R.D. \& Payne, A.H. (1983) Luteinizing hormone receptors and testosterone production in whole testes and purified Leydig cells from the mouse: differences among inbred strains. Endocrinology 112, 1696-1701.

Tamhane, A.C. (1976) Multiple comparisons in model I one-way ANOVA with unequal variances. Mimeographed paper, Dept. of Industrial Engineering and Management Science, Northwestern Univ., Evanston, IL, U.S.A.

Wolfe, H.G., Bartke, A., Amador, A., Van Sickle, M., Dalterio, S. \& Brown, D. (1981) Testicular function in strains of mice selected for differences in gonadotrophin-induced ovulation rate. J. Endocr. 90, $367-373$. 